\title{
Hubungan Dukungan Sosial dan Spiritual Penderita HIV/AIDS dengan Kualitas Hidup Penderita HIV/AIDS
}

\author{
${ }^{1}$ A. G.Baidowi*, ${ }^{2}$ K. Khotima, ${ }^{3}$ S. A. Andayani \\ 1,2,3Program Studi Keperawatan, Fakultas Kesehatan, Universitas Nurul Jadid \\ *Email Korespondensi: abdulghoni576@gmail.com
}

\section{Kata kunci : \\ Dukungan Sosial, \\ Dukungan Spritual, \\ Kualitas Hidup, \\ Penderita HIV/AIDS \\ Keywords : \\ Social Support, \\ Spiritual Support, \\ Quality Of Life, \\ Sufferers of HIV/AIDS}

Info Artikel:

Tanggal dikirim:

14 Oktober 2019

Tanggal direvisi:

22 Oktober 2019

\section{Tanggal diterima :}

28 November 2019

\section{DOI Artikel:}

10.33862/citradelima. v3i2.87

Halaman: $118-126$

\begin{abstract}
Abstrak
Menurut Bare dan Smeltzer, HIV/AIDS tidak hanya menimbulkan masalah fisik namun juga menimbulkan masalah sosial dan psikologis. Masalah sosial pada orang dengan HIV/AIDS berupa adanya stigma dan diskriminasi dari lingkungan sekitar. Mengetahui hubungan dukungan sosial dan spiritual penderita HIV/AIDS dengan kualitas hidup penderita HIV/AIDS di RSU dr. H. Koesnadi Kabupaten Bondowoso. Penelitian ini menggunakan Korelasi Observasi, dengan pendekatan Cross Sectional dimana peneliti menggunakan kuesioner kepada 43 responden dengan menggunakan tekhnik total sampling.Penelitian ini menggnakan SPSS uji Spearman Rank dengan nilai signifikansi (Asymp. Sig) diperoleh hasil antara perilaku sebelum dan sesudah penyuluhan sebesar $0,001<0,05$, artinya ho ditolak dan ha diterima. Ada hubungan dukungan sosial dan spiritual penderita HIV/AIDS dengan kualitas hidup penderita HIV/AIDS di RSU dr. H. Koesnadi Kabupaten Bondowoso.
\end{abstract}

\section{Relationship of Social and Spiritual Support of HIV/AIDS with the Quality of Life of HIV/AIDS Sufferers}

\begin{abstract}
According to Bare and Smeltzer, HIV/AIDS not only poses physical problems but also causes social and psychological problems. Social problems in people with HIV/AIDS in the form of stigma and discrimination from the surrounding environment. Know the relationship of social and spiritual support of people with HIV/AIDS with the quality of life of HIV/AIDS in the RSU Dr. H. Koesnadi District Bondowoso. This study uses observation correlation, with a Cross- Sectional approach whereby researchers use questionnaires to 43 respondents using the total sampling technique.This research is going for SPSS test Spearman Rank with significance value (Asymp. Sig) was obtained by the results of the prior and following conduct of $0.001<0.05$, meaning Ho was rejected and Ha accepted. There is a relationship of social and spiritual support of people with HIV/AIDS with the quality of life of HIV/AIDS in the RSU Dr. H. Koesnadi District Bondowoso.
\end{abstract}

\section{PENDAHULUAN}

Human Immunodeficiency Virus (HIV) atau Acquired Immune Deficiency Syndrome (AIDS) merupakan masalah kesehatan terbesar di dunia yang terus meningkat dengan angka kematian yang tinggi. Menurut United Nation on AIDS (2016), HIV/AIDS merupakan masalah kesehatan masyarakat yang bersifat global dengan jumlah sebanyak 36.7 juta orang meninggal karena virus HIV.
Di Indonesia, berdasarkan data yang diperoleh dari kementerian kesehatan RI, diketahui bahwa pada tahun 2015 terdapat sebanyak 30.935 kasus HIV dan sebanyak 7.185 kasus AIDS di Indonesia, sementara pada tahun 2016 jumlah kasus HIV di Indonesia mengalami penurunan menjadi 27.963 kasus dan AIDS menjadi 3.679 kasus. (Departemen Kesehatan RI 2015)

Kementerian kesehatan RI pada September 2017 melaporkan bahwa Jawa Timur merupakan salah

http://jurnalilmiah.stikescitradelima.ac.id/index.php/JI Vol.3,No.2, Januari 2020 
satu Provinsi dengan kasus HIV terbanyak yaitu 2.875 kasus HIV dan sebanyak 569 kasus AIDS, Kabupaten Bondowoso memiliki 147 kasus HIV/AIDS pada tahun 2018 dan 43 kasus diantaranya mendapatkan perawatan di RSU Dr. H.Koesnadi Kabupaten Bondowoso.

Pemahaman kebanyakan orang masih keliru tentang HIV/AIDS. HIV/AIDS diasumsikan hanya menjadi masalah bagi orang dengan perilaku seks yang menyimpang dan sering dikaitkan dengan mereka yang dinilai tidak bermoral, pendosa dan sebagainya. Stigma yang ada di masyarakatd apat menimbulkan diskriminasi terhadap orang dengan HIV/AIDS (ODHA), dan hal tersebut harus segera mendapatkan penanganan. (Yusnita, L.E. 2012. Hapus Stigma dan Diskriminasi,Pahami HIV \& AIDS)

Perlakuan diskriminatif dapat berasal dari keluarga sendiri, teman dan kerabat, masyarakat sekitar, ataupun dari pemerintah. Stigma dan deskriminasi menimbulkan dampak psikologi yang berat bagaimana ODHA memandang diri mereka. Kondisi ini dapat mendorong terjadinya depresi, kurang penghargaan diri, keputusasaan, bahkan keinginan bunuh diri atau merusak dirinya. Kurangnya dukungan dari lingkungan (dukungan material, informasional, emosional, sosial, atau spiritual) akan membuat kualitas hidup ODHA memburuk. Berdasarkan hasil wawancara yang dilakukan terhadap $\mathrm{X}$ yang merupakan orang dengan HIV/AIDS, diketahui bahwa orang dengan HIV/AIDS memiliki, perasaan putus asa, adanya emosi yang tidak stabil serta memilih mengasingkan diri dari lingkungan (Wawancara, 20 Februari 2019).

Berdasarkan hasil penelitian yang dilakukan oleh Rahakbauw tahun 2016 diketahui bahwa pada orang dengan HIV/AIDS mengalami masalah psikologis yang tercermin dalam ketakutan, kecemasan, kesedihan, kebingungan, kemarahan dan kehilangan rasa percaya diri serta, keputusasaan ketika mengetahui tentang penyakit yang dialami. Hal ini diperkuat dengan pernyataan Hawari bahwa orang dengan HIV/AIDS pada umumnya mengalami gangguan stres, kecemasan, depresi bahkan ada yang sampai memiliki keinginan untuk bunuh diri. Dalam hal ini, bunuh diri merupakan efek psikologis yang lebih berat yang dialami oleh orang dengan HIV/AIDS.

Nasronudin mengungkapkan bahwa salah satu faktor yang memiliki peranan penting dalam kualitas hidup ODHA adalah dukungan sosial. Dukungan sosial dapat diartikan sebagai suatu kenyamanan, perhatian, penghargaan, atau bantuan yang dirasakan individu dari orang lain atau kelompok lain. Dengan adanya dukungan sosial ini maka seseorang akan merasa dihargai, dicintai, dan merasa menjadi bagian dari masyarakat, sehingga ODHA tidak merasa didiskriminasi yang nantinya dapat berdampak positif bagi kesehatannya.

Spiritualitas merupakan dimensi penting bagi kesejahteraan perasaan pada orang dengan HIV/AIDS. Superkertia, Astuti, dan Lestari (2016) bahwa ada hubungan searah yang sangat kuat antara tingkat spiritualitas dan tingkat kualitas hidup pada orang dengan HIV/AIDS. Berdasarkan penelitian yang dilakukan oleh Douaihy dan Singh (2001) bahwa terdapat $62,6 \%$ orang dengan HIV/AIDS memiliki kualitas hidup yang rendah yang dipengaruhi oleh beberapa faktor yaitu faktor sosial, faktor psikologis, dan faktor spiritual. Permasalahan psikososial pada orang dengan HIV/AIDS dapat dinetralisir atau dihilangkan dengan kehidupan spiritualitas yang kuat. Spiritualitas merupakan dimensi penting bagi kesejahteraan perasaan pada orang dengan HIV/AIDS.

Spiritualitas pada orang yang terinfeksi HIV dianggap sebagai jembatan antara perasaan putus asa dan kebermaknaan dalam hidup. Spiritualitas merupakan bagian dari kualitas hidup yang berada dalam domain kapasitas diri atau being yang terdiri dari nilai- nilai personal, standar personal dan kepercayaan. ( University of Toronto. (2010). The Quality of Live Model.) Berdasarkan latar belakang diatas, peneliti tertarik untuk mempelajari lebih dalam lagi mengenai hubungan dukungan sosial dan spiritual penderita HIV/AIDS dengan kualitas hidup penderita HIV/AIDS di RSU dr. H. Koesnadi Kabupaten Bondowoso .

\section{METODE}

Desain penelitian yang digunakan adalah metode Korelasi Observasi, dengan pendekatan Cross Sectional. Penelitian korelasional mengkaji hubungan antara variable yang bertujuan mengungkapkan hubungan korelatif antar variabel. Pada jenis ini, variabel independen dan dependen dinilai secara simultan pada suatu saat, jadi tidak ada tindak lanjut. Sampel pada penelitian ini yaitu sebanyak 43 responden.

http://jurnalilmiah.stikescitradelima.ac.id/index.php/JI Vol.3,No.2, Januari 2020 


\section{HASIL DAN PEMBAHASAN}

1. Data Umum

a. Karakteristik Responden Berdasarkan Jenis kelamin

Tabel 5.1 Distribusi frekuensi berdasarkan jenis kelamin.

\begin{tabular}{cccc}
\hline No & $\begin{array}{c}\text { Jenis } \\
\text { kelamin }\end{array}$ & Frekuensi & Prosentase \\
\hline 1. & Laki-laki & 27 & 62,79 \\
2. & Perempuan & 16 & 37,21 \\
\hline & Jumlah & 43 & 100 \\
\hline
\end{tabular}

Data primer : diolah tahun 2019

Berdasarkan tabel 5.1 menunjukkan bahwa sebagian besar responden berjenis kelamin laki-laki sebanyak 27 orang $(62,79 \%)$.

\section{b. Karakteristik Responden Berdasarkan Usia}

Tabel 5.2 Distribusi frekuensi berdasarkan usia

\begin{tabular}{cccc}
\hline No & Usia & Frekuensi & Prosentase \\
\hline 1. & $12-17$ Tahun & 1 & 2,32 \\
2. & $18-35$ Tahun & 11 & 25,58 \\
3. & $36-45$ Tahun & 18 & 41,86 \\
4. & $>45$ Tahun & 13 & 30,24 \\
\hline & Jumlah & 43 & 100 \\
\hline
\end{tabular}

Data primer : diolah tahun 2019

Berdasarkan tabel 5.2 menunjukkan bahwa sebagian besar responden berada pada kelompok usia 36 - 45 tahun sebanyak 18 orang $(41,86 \%)$.

\section{c. Karakteristik Responden Berdasarkan Pendidikan}

Tabel 5.3 Distribusi frekuensi berdasarkan pendidikan.

\begin{tabular}{cccc}
\hline No & Pendidikan & Frekuensi & Prosentase \\
\hline 1. & Tidak sekolah & 0 & 0 \\
\hline 2. & SD & 7 & 16,28 \\
\hline 3. & SMP & 9 & 20,93 \\
\hline 4. & SMA & 23 & 53,49 \\
\hline 5. & Akademi / PT & 4 & 9,3 \\
\hline & Jumlah & 43 & 100
\end{tabular}

Data primer : diolah tahun 2019

Berdasarkan tabel 5.3 menunjukkan bahwa sebagian besar responden berada pada kelompok tingkat pendidikan SMA sebanyak 23 orang $(53,49 \%)$.

d. Karakteristik Responden Berdasarkan
Pekerjaan

Tabel 5.4 Distribusi frekuensi berdasarkan pekerjaan.

\begin{tabular}{cccc}
\hline No & Pekerjaan & Frekuensi & Prosentase \\
\hline 1. & Tani & 0 & 0 \\
2. & IRT & 8 & 18,60 \\
3. & Wiraswasta & 21 & 48,84 \\
4. & Swasta & 14 & 32,56 \\
5. & PNS & 0 & 0 \\
\hline & Jumlah & 43 & 100
\end{tabular}

Data primer : diolah tahun 2019

Berdasarkan tabel 5.4 menunjukkan bahwa sebagian besar responden bekerja sebagai wiraswasta sebanyak 21 orang $(48,84 \%)$.

\section{Data Khusus}

a. Dukungan sosial penderita HIV/AIDS.

Tabel 5.5 Distribusi frekuensi dukungan sosial penderita HIV/AIDS di RSU dr. H. Koesnadi Bondowoso.

\begin{tabular}{lccc}
\hline No & Dukungan sosial & Frekuensi & Prosentase \\
\hline 1. & Baik & 6 & 13,95 \\
2. & Sedang & 21 & 48,84 \\
3. & Tidak baik & 16 & 37,21 \\
& & & \\
\hline & Jumlah & 43 & 100 \\
\hline
\end{tabular}

Data primer : diolah tahun 2019

Dari tabel 5.5 menunjukkan bahwa sebagian besar jumlah responden dalam kelompok dukungan sosial kategori sedang sebanyak 21 orang $(48,84 \%)$.

\section{b. Dukungan spiritual penderita HIV/AIDS.}

Tabel 5.6 Distribusi frekuensi dukungan spiritual penderita HIV/AIDS di RSU dr. H. Koesnadi Bondowoso.

\begin{tabular}{cccc}
\hline No & $\begin{array}{c}\text { Dukungan } \\
\text { spiritual }\end{array}$ & Frekuensi & Prosentase \\
\hline 1. & Baik & 19 & 44,19 \\
2. & Sedang & 24 & 55,81 \\
3. & Tidak baik & 0 & 0 \\
\hline & Jumlah & 43 & 100
\end{tabular}

Data primer : diolah tahun 2019

Dari tabel 5.6 menunjukkan bahwa sebagian besar responden dalam kelompok dukungan spiritual kategori sedang sebanyak 24 orang $(55,81 \%)$.

c. Kualitas hidup penderita HIV/AIDS di RSU dr. H. Koesnadi Kabupaten Bondowoso.

http://jurnalilmiah.stikescitradelima.ac.id/index.php/JI Vol.3,No.2, Januari 2020 
Tabel 5.7 Distribusi Frekuensi Kualitas hidup penderita HIV/AIDS di RSU dr. H. Koesnadi Kabupaten Bondowoso.

\begin{tabular}{cccc}
\hline No & Kualitas hidup & Frekuesi & Presentase \\
\hline 1. & Baik & 13 & 30,24 \\
2. & Sedang & 16 & 37,20 \\
3. & Buruk & 14 & 32,56 \\
& & & \\
\hline & Jumlah & 43 & 100 \\
\hline
\end{tabular}

Data primer : diolah tahun 2019

Dari tabel 5.7 menunjukkan bahwa sebagian besar jumlah responden dalam kelompok kualitas hidup kategori sedang sebanyak 16 orang $(37,20 \%)$.

d. Hubungan dukungan sosial dengan kualitas hidup penderita HIV/AIDS

Tabel 5.8 Tabulasi silang hubungan dukungan sosial penderita HIV/AIDS dengan kualitas hidup penderita HIV/AIDS di RSU dr. H. Koesnadi Bondowoso.

\begin{tabular}{|c|c|c|c|c|c|c|c|}
\hline \multicolumn{8}{|c|}{ Kualitas Hidup } \\
\hline \multirow[t]{13}{*}{$\begin{array}{l}\text { Dukun } \\
\text { gan } \\
\text { Sosial }\end{array}$} & & Baik & $\begin{array}{c}\text { Seda } \\
\text { ng }\end{array}$ & $\begin{array}{c}\text { Bur } \\
\text { uk }\end{array}$ & $\begin{array}{c}\text { tot } \\
\text { al }\end{array}$ & $\mathrm{R}$ & $\begin{array}{c}\mathrm{p}^{-} \\
\text {valu } \\
\mathrm{e}\end{array}$ \\
\hline & Baik & 3 & 2 & 1 & 6 & 0 & 0,00 \\
\hline & & $(6,9$ & $(4,6)$ & 92,3 & (1 & 83 & 2 \\
\hline & & 8) & & ) & $\begin{array}{c}3,9 \\
5)\end{array}$ & 8 & \\
\hline & Seda & 7 & 9 & 5 & 21 & & \\
\hline & ng & $\begin{array}{c}(16 \\
6)\end{array}$ & $\begin{array}{c}(20, \\
9)\end{array}$ & $\begin{array}{c}(11, \\
6)\end{array}$ & $\begin{array}{c}(4 \\
8,8 \\
4)\end{array}$ & & \\
\hline & Tida & 3 & 5 & 8 & 16 & & \\
\hline & $\mathrm{k}$ & $(6,9$ & $(11$, & $(18$ & $(3$ & & \\
\hline & baik & 8) & 6) & 6) & 7,2 & & \\
\hline & & & & & 1) & & \\
\hline & total & 13 & 16 & 14 & 43 & & \\
\hline & & $(30$ & $(37$, & (32, & (1 & & \\
\hline & & 24) & 20) & 56) & 00 & & \\
\hline
\end{tabular}

Data primer : diolah tahun 2019

Dari tabel 5.8 diatas menyatakan bahwa prosentase responden menyatakan dukungan sosial sedang dengan kualitas hidup sedang sebanyak 9 orang (20,93\%), sedangkan hasil tabulasi silang paling sedikit yaitu dukungan sosial baik, dengan kualitas hidup buruk yaitu 1 responden $(2,33 \%)$.

Hasil pengujian pada tabel 5.8 di atas menunjukan bahwa uji Spearman Rank bahwa nilai signifikan atau sign.(2 tailed) sebesar 0.002, karena nilai sig.(2 tailed) $0.002<$ dari 0.005 , maka ada hubungan yang signifikan (berarti) antara variabel dukungan sosial dan kualitas hidup.

Nilai Rho 0,838 menunjukan tingkat kekuatan hubungan yang berarti hubungan antara variabel dukungan sosial dengan kualitas hidup adalah kuat. Selain itu nilai Rho 0,838 juga menerangkan tentang arah hubungan adalah positif. Sehingga hubungan kedua variabel tersebut bersifat searah, dengan demikian dapat diartikan bahwa semakin baik dukungan sosial maka kualitas hidup juga akan semakin baik.

\section{e. Dukungan spiritual dengan kualitas hidup penderita HIV/AIDS.}

Tabel 5.9 Tabulasi silang dukungan spiritual penderita HIV/AIDS dengan kualitas hidup penderita HIV/AIDS di RSU dr. H. Koesnadi Kabupaten Bondowoso.

\begin{tabular}{|c|c|c|c|c|c|c|c|}
\hline & & \multicolumn{6}{|c|}{ Kualitas hidup } \\
\hline & & Baik & $\begin{array}{l}\text { Seda } \\
\text { ng }\end{array}$ & Buruk & Total & Rho & $P$ \\
\hline & & $\mathrm{F}$ & $\mathrm{F}$ & $\mathrm{F}$ & $\mathrm{F}$ & & \\
\hline & Baik & 9 & 4 & 6 & 19 & 0.966 & 0,00 \\
\hline & & $(20,9)$ & $(9,3)$ & $(13,9)$ & $(44,19)$ & & 4 \\
\hline $\begin{array}{l}\text { Dukun } \\
\text { gan }\end{array}$ & Sedang & $\begin{array}{c}4 \\
(9,3)\end{array}$ & $\begin{array}{c}12 \\
(27,9)\end{array}$ & $\begin{array}{c}8 \\
(18,6)\end{array}$ & $\begin{array}{c}24 \\
(55,81)\end{array}$ & & \\
\hline $\begin{array}{l}\text { spiritua } \\
1\end{array}$ & $\begin{array}{l}\text { Tidak } \\
\text { baik }\end{array}$ & 0 & 0 & 0 & 0 & & \\
\hline & Total & $\frac{13}{(30,24)}$ & $\begin{array}{c}16 \\
(37,2)\end{array}$ & $\frac{14}{(32,56)}$ & 43 & & \\
\hline
\end{tabular}

Data primer : diolah tahun 2019

Dari tabel 5.9 diatas menyatakan bahwa prosentase responden menyatakan dukungan spiritual sedang dengan kualitas hidup sedang sebanyak $(27,90 \%)$, sedangkan hasil tabulasi silang paling sedikit yaitu dukungan spiritual tidak baik, dengan kualitas hidup buruk yaitu 0 responden $(0,00 \%)$.

Hasil pengujian pada tabel 5.8 di atas menunjukan bahwa uji Spearman Rank bahwa nilai signifikan atau sign.(2 tailed) sebesar 0.004, karena nilai sig.(2 tailed) $0.004<$ dari 0.005 , maka ada hubungan yang signifikan (berarti) antara variabel Spiritual dan kualitas hidup. Nilai Rho 0,966 menunjukan tingkat kekuatan hubungan yang berarti hubungan antara variabel dukungan spiritual dengan

http://jurnalilmiah.stikescitradelima.ac.id/index.php/JI Vol.3,No.2, Januari 2020 
kualitas hidup adalah kuat. Selain itu nilai Rho 0,966 juga menerangkan tentang arah hubungan adalah positif. Sehingga hubungan kedua variabel tersebut bersifat searah, dengan demikian dapat diartikan bahwa semakin baik dukungan spiritual maka kualitas hidup juga akan semakin baik.

\section{f. Dukungan sosial dan spiritual dengan kualitas hidup penderita HIV/AIDS.}

Tabel 5.10 Tabulasi regresi dukungan sosial dan spiritual penderita HIV/AIDS dengan kualitas hidup penderita HIV/AIDS di RSU dr. H. Koesnadi Kabupaten Bondowoso.

\begin{tabular}{|c|c|c|c|c|c|c|}
\hline & Model & $\begin{array}{l}\text { Sum of } \\
\text { Squares }\end{array}$ & $\mathrm{df}$ & $\begin{array}{c}\text { Mean } \\
\text { Squar } \\
\mathrm{e}\end{array}$ & $\mathrm{F}$ & $\mathrm{Sig}$ \\
\hline \multirow[t]{3}{*}{1} & Regressiol & 13.479 & 2 & 6.740 & .756 & .002 \\
\hline & Residual & 356.567 & 40 & 8.914 & & \\
\hline & Total & 370.047 & 42 & & & \\
\hline
\end{tabular}

a.Dependent Variable: kualitas hidup

b.Predictors: (Constant), dukungan sosial, dukungan spiritual

Hasil pengujian pada tabel 5.10 di atas menunjukan bahwa nilai signifikan untuk pengaruh dukungan sosial dan dukungan spiritual secara simultan terhadap kualitas hidup adalah sebesar $0.002<0.005$ dan nilai $\mathrm{F}$ hitung $0.756>\mathrm{F}$ tabel 0.410 , maka dapat disimpulkan hipotesis diterima, yaitu ada hubungan dukungan sosial dan spiritual penderita HIV/AIDS dengan kualitas hidup penderita HIV/AIDS di RSU dr. H. Koesnadi Bondowoso.

\section{PEMBAHASAN}

\section{Hubungan dukungan sosial penderita HIV/AIDS dengan kualitas hidup penderita HIV/AIDS di RSU dr. H. Koesnadi Bondowoso .}

Dari tabel 5.7 di atas menunjukan bahwa nilai signifikan atau sign.(2 tailed) sebesar 0.002, angka signifikansi pada penelitian ini memiliki nilai yang lebih kecil dari 0,05 dan sesuai dengan kaidah yang telah ditentukan bahwa jika angka signifikansi hasil penelitian < 0,05, maka H0 ditolak dan Ha diterima. Hal ini menandakan bahwa ada hubungan positif antara dukungan sosial dengan kualitas hidup pada orang dengan HIV dan AIDS (ODHA) di RSU dr.H. Koesnadi Bondowoso.
Hasil penelitian ini sejalan dengan hasil penelitian yang dilakukan oleh Tuapattinaja (2014) bahwa dukungan sosial yang diterima ODHA mampu meredakan kecemasan atau kondisi stres yang muncul terkait dengan sakit yang diidapnya, sehingga ODHA menjadi lebih tenang dan mampu mengarah pada kualitas hidup yang lebih baik.

Kualitas hidup merupakan kemampuan individu dalam menikmati kepuasan selama hidupnya (Ventegodt, Merrick dan Andersen, 2013). Individu harus mampu berfungsi secara fisik, spiritual, psikologis, dan sosial demi mencapai kualitas hidup yang baik. Kualitas hidup pada ODHA itu sendiri memang cukup rentan untuk mengalami penurunan akibat adanya masalah secara fisiologis, maupun masalah secara psikologisnya. ODHA menjadi sangat rentan terserang penyakit akibat terinfeksi HIV yang merusak sistem kekebalan tubuh. Penurunan sistem kekebalan tubuh ini akan menyebabkan ODHA mengalami gejala- gejala menyerupai flu, seperti: lemas, batuk yang berkepanjangan, demam, sakit kepala, nyeri otot, nafsu makan buruk, mual, pembengkakan kelenjar, dan bercak di kulit (Greene, Derlega, Yep, \& Petronio, 2013).

Tidak jarang bahwa ODHA mengalami penurunan berat badan secara drastis hingga sering terkapar lemas ditempat tidur akibat dari infeksi HIV. ODHA akhirnya akan mengalami kesulitan untuk melakukan aktivitas sehari- hari, bahkan mereka tidak mampu untuk bekerja lagi. Ketidakmampuan ODHA untuk melakukan aktivitas sehari-hari dan bahkan ketidakmampuan untuk bekerja telah mengindikasikan bahwa ODHA mengalami penurunan kualitas hidup. ODHA sebenarnya tidak hanya mengalami tekanan akibat adanya virus HIV yang menyerang sistem kekebalan tubuh saja, tetapi ODHA juga dihadapkan pada stigma dan diskriminasi.

Sesuai dengan yang diungkapkan oleh Smetzer dan Bare (2012) bahwa ODHA sering mendapat stigma akibat dari virus yang menginfeksinya. ODHA sering disebut sebagai orang yang mengidap penyimpangan seksual atau gay, wanita nakal, dan salah pergaulan. Melalui stigma tersebut, ODHA kemudian dikucilkan dan tanpa disadari bahwa tindakan tersebut sebenarnya telah mempengaruhi kondisi psikologis ODHA. Hal ini mengantarkan ODHA pada kondisi stres, depresi, putus asa dan menutup diri. ODHA akan memilih untuk merahasiakan status kesehatannya dari keluarga, teman maupun kerabat dekatnya, sehingga ODHA pun tidak

http://jurnalilmiah.stikescitradelima.ac.id/index.php/JI Vol.3,No.2, Januari 2020 
mampu mendapatkan dukungan yang seharusnya diperoleh (Sawitri \& Wirawan, 2012).

ODHA sebenarnya membutuhkan dukungan, bukan dikucilkan agar harapan hidup ODHA menjadi lebih panjang. Sarafino (2011) mengungkapkan bahwa dengan adanya dukungan sosial maka akan tercipta lingkungan kondusif yang mampu memberikan motivasi maupun memberikan wawasan baru bagi ODHA dalam menghadapi kehidupannya. Dukungan sosial ini dapat meminimalkan tekanan psikososial yang dirasakan ODHA, sehingga ODHA dapat memiliki gaya hidup yang lebih baik dan dapat memberikan respon yang lebih positif terhadap lingkungan sosialnya. Selain itu, dengan adanya dukungan sosial ini maka ODHA akan merasa dihargai, dicintai, dan merasa menjadi bagian dari masyarakat, sehingga ODHA tidak merasa didiskriminasi yang nantinya dapat berdampak positif bagi kesehatannya.

\section{Hubunga dukungan spiritual penderita HIV/AIDS dengan kualitas hidup penderita HIV/AIDS di RSU dr. H. Koesnadi Bondowoso.}

Penelitian ini dilakukan bertujuan untuk mengetahui hubungan antara spiritualitas dengan kualitas hidup pada orang dengan HIV/AIDS. Berdasarkan analisis korelasi yang telah dilakukan sebelumnnya, diketahui bahwa bahwa nilai signifikan atau sign.(2 tailed) sebesar 0.004, karena nilai sig.(2 tailed) $0.004<$ dari 0.005 , pada variabel kualitas hidup dan spiritualitas pada orang dengan HIV/AIDS, hal ini berarti hipotesis yang diajukan diterima.

Hal tersebut menunjukkan bahwa semakin tinggi tingkat spiritualitas individu, maka semakin baik kualitas hidup yang dimiliki oleh individu, begitu pula sebaliknya bahwa semakin baik kualitas hidup seorang individu maka akan semakin tinggi tingkat spiritualitas yang dimiliki. Hasil penelitian tersebut didukung oleh penelitian yang dilakukan oleh Superkertia, Astuti dan Lestari (2016) yang menemukan bahwa ada hubungan searah yang sangat kuat dan signifikan antara tingkat spiritualitas dengan kualitas hidup pada orang dengan HIV/AIDS.

Dalam penelitian yang dilakukan oleh Yuzefo, Sabrian, dan Novayelinda (2013) diketahui bahwa terdapat beberapa faktor yang mempengaruhi kualitas hidup, salah satunya adalah faktor spiritualitas. Dalam penelitian ini diketahui bahwa responden berjumlah 43 orang dengan 16 orang memiliki kualitas hidup sedang $(37,20 \%)$.

Lubkin dan Larsen, (2012) dalam penelitiannya mengatakan bahwa spiritual adalah segala sesuatu mengenai kehidupan, bagian terdalam dari individu, memberikan harapan, meningkatkan keterkaitan hubungan dan meningkatkan kualitas hidup yang lebih baik. Hal tersebut sejalan dengan penelitian Tuck dan Thinganjana (2010) yang mengatakan spiritualitas adalah sumber inspirasi berupa harapan, iman dan kekuatan untuk memelihara hidup atau menerima pemberian, selain itu merupakan proses pencarian akan makna hidup yang diwujudkan dengan harapanharapan yang baik untuk kehidupan Selain itu, Basavaraj, Navya, dan Rashmi (2010), juga menjelaskan beberapa prediktor penting yang berpengaruh terhadap kualitas hidup pada orang dengan HIV/AIDS, yaitu adanya kesejahteraan psikologis, dukungan sosial, strategi koping, kesejahteraan spiritual, manifestasi fisik komorbiditas psikiatrik, bahkan termasuk pula ART (Antiretroviral Therapy).

Dalam penelitian yang dilakukan oleh Burhan, Fourianalistyawati dan Zuhroni (2014) yang menggunakan pendekatan kualitatif dengan metode studi kasus dan pengumpulan data dengan observasi dan wawancara mendalam. Berdasarkan hasil penelitian, diketahui bahwa subjek merasa lebih bermanfaat dibandingkan dengan sebelum mendapatkan status HIV/AIDS, hal yang dialami saat ini dianggap sebagai peringatan sekaligus anugerah dari Allah SWT agar dapat meninggalkan perilaku buruk dan bersikap lebih sehat. Dari hasil penelitian tersebut, diketahui bahwa orang dengan HIV/AIDS membutuhkan spiritualitas untuk meningkatkan kualitas hidup.

Berdasarkan penjabaran di atas, dapat disimpulkan bahwa variabel spiritualitas memiliki hubungan yang signifikan terhadap kualitas hidup pada orang dengan HIV/AIDS, meskipun bukan sebagai prediktor utama dalam memprediksi dan meningkatkan kualitas hidup. Hal ini dikarenakan masih banyak faktor lain yang dapat menjadi prediktor dalam meningkatkan kualitas hidup. Namun, spiritualitas dapat membantu orang dengan HIV/AIDS dalam meningkatkan kesejahteraan psikologis diimbangi dengan faktor-faktor lainnya yang juga berpengaruh terhadap kualitas hidup secara menyeluruh.

http://jurnalilmiah.stikescitradelima.ac.id/index.php/JI Vol.3,No.2, Januari 2020 
3. Tabulasi silang dukungan sosial dan spiritual penderita HIV/AIDS dengan kualitas hidup penderita HIV/AIDS di RSU dr. H. Koesnadi Kabupaten Bondowoso.

Dari tabel 5.9 di atas menunjukan bahwa nilai signifikan $F$ change sebesar 0.001 , karena nilai signifikan $\mathrm{F}$ change $0.001<$ dari 0.005 , maka ada hubungan yang signifikan (berarti) antara variabel dukungan sosial dan spiritual terhadap kualitas hidup.

Hal ini menunjukkan bahwa hipotesis yang menyatakan ada hubungan antara dukungan social dan spiritual dengan kualitas hidup penderita HIV/AIDS di RSU dr. H.Koesnadi Bondowoso terbuktiatau signifikan karena probabilitasnya kurang dari $5 \%$. Hasil penelitian ini juga telah membuktikan atau sesuai dengan hasil penelitian dari Dow, et, all., (2010) yang menyimpulkan bahwa kualitas hidup berkaitan dengan efek fisiologis, kualitas dalam interaksi dengan sosial, prestasi pekerjaan atau aktifitas harian serta distres spiritual, adalah gambaran dari upaya membangun eksistensi diri yang tidak banyak dipengaruhi oleh dukungan social saja namun spiritual juga. Adanya hubungan antara dukungana sosial dengan kualitas hidup pada penderita HIV/AIDS tersebut sesuai denganhasil penelitian Caturinata (2010) yang menyebutkan bahwa dukungan sosial pada penderita HIV/AIDSdipengaruhi oleh beberapa faktoryaitu kondisi ekonomi, respon darilingkungan, dan kepribadian penderita HIV/AIDS itu sendiri.

\section{SIMPULAN}

Dari hasil penelitian tentang hubungan dukungan sosial dan spiritual penderita HIV/AIDS dengan kualitas hidup penderita HIV/AIDS di RSU dr. H. Koesnadi Kabupaten Bondowoso terhadap 43 responden, penulis mendapatkan kesimpulan sebagai berikut

Ada pengaruh dukungan sosial keluarga terhadap kualitas hidup penderita HIV/AIDS di Puskesmas Cermee Kabupaten Bondowoso, dengan nilai $\mathrm{p}$ value sebesar 0.002 .

Ada pengaruh dukungan spiritual keluarga terhadap keluarga terhadap kualitas hidup penderita HIV/AIDS di Puskesmas Cermee Kabupaten Bondowoso dengan nilai p value sebesar 0.004 .
Ada pengaruh dukungan sosial dan spiritual keluarga terhadap kualitas hidup penderita HIV/AIDS di Puskesmas Cermee Kabupaten Bondowoso dengan nilai $\mathrm{p}$ value sebesar 0.001 .

\section{DAFTAR PUSTAKA}

Abdul Gani Soulissa,2014 dalam jurnal PDGI, Hubungan kehamilan dan penyaki periodontal,No.3.

Alimul H,A. Aziz.2009. Kebutuhan dasar Manusia Aplikasi Konsep dan Proses Perawatan. Jakarta: Salemba Medika.

Alimul Hidayat, Aziz. 2011. Metode Penelitian Kebidanan dan Teknik Analisis Data. Jakarta: Salemba Medika.

Al-Qur`an dan Terjemahannya. 2014. Jakarta: Pustaka al-Fatih

Anandhara Indriani K dkk ,2016, Pencegahan Tranmisi Vertikal Hepatitis B, Jurnal Penyakit Dalam Indonesia, Vol.3, No.4 (Desember)

Arikunto, S. (2012). Prosedur penelitian Suatu Pendekatan Praktek. Jakarta: Rineka Cipt. Azwar, 2011, Sikap Manusia Teori dan Pengukurannya, Yogyakarta: Pustaka Pelajar.

Bidang P2,2018, Rekap Ibu Hamil dengan Pemeriksaan HbsAg Positif, Dinas Kesehatan kabupaten Bondowoso.

Budiman, Riyanto 2012.Penyuluhan Kesehatan Pada Remaja, Keluarga, Lansia dan Masyarakat. Jakarta: Trans Info Media.

CDC, 2016. Hepatitis b dalam Naskah Publikasi, Kejadian Infeksi Hepatitis B pada Anak Yang dilahirkan Oleh Ibu dengan Positif HbsAg.Program Pascasarjana Fakultas Kedokteran Universitas Gadjah Mada, Yogyakarta.

Cuwin, 2009.Sikap Manusia, Teori dan Pengukurannya. Yogyakarta: Pustaka Pelajar.

Departemen Kesehatan Republik Indonesia, 2012. Profil Kesehatan Indonesia 2012. Jakarta: Badan Penerbit Dinas Kesehatan Indonesia.

http://jurnalilmiah.stikescitradelima.ac.id/index.php/JI Vol.3,No.2, Januari 2020 
Depkes RI, 2017, Profil Kesehatan Indonesia. Dr,J.B Suharjo B Cahyono,2010,Cegah Kanker Hati,Yogyakarta,Kanisius.

Effendy, S. 2011, Teknik Penyuluhan dan Pemberdayaan Masyarakat, Ghalia Indonesia, Bogor.

Firda, Yani T. (2013) Panduan Klinis Kehamilan Dan Persalinan. Yogjakarta : D-Medika (Anggota IKAPI)

Hidayat A.A, 2011, Metode Penelitian Kebidanan dan Tekhnik Analisa Data, Jakarta: Salemba.

Joyce Bratanata dkk,2015, saw dan chu dalam Jurnal, Proporsi Inveksi Virus Hepatitis B Tersamar pada pasien yang Terinfeksi HIV. Vol.2, No.3(Oktober) 127.

Kamus Besar Bahasa Indonesia, 2012, Jakarta: Erlangga

Kemenkes RI. 2017. Petunjuk Teknis Deteksi Dini Hepatitis B dan C Pada Kelompok Masyarakat Berisiko Tinggi. Ditjen PP dan PL Kementerian Kesehatan RI. Jakarta.

Kementrian Kesehatan dalam Nova oktavia dan Erly zainal,2018,Jurnal Kebidanan dan Keperawatan;Pelaksana Konseling Pra- test Meningkatkan Tingkat Pemahaman, vol.14.

Kementrian Kesehatan RI,2014, Pedoman Manajemen Pengendalian Hepatitis, Diare dan Infeksi Saluran Pencernaan. Direktorat Jenderal P2.

Lucie, S., 2011, Teknik Penyuluhan Kesehatan dan Pemberdayaan Masyarakat, Ghalia Indonesia, Bogor.

Lukmanto B, 2016. Hepatitis Pada Kehamilan.Diakses Tanggal 14 Februari 2019

Nasir Ahmad,2016, Naskah Publikasi, Kejadian Infeksi Hepatitis B pada Bayi dan Anak Yang Dilahirkan Dari Ibu dengan HbsAg Positif.Program Pascasarjana Fakultas Kedokteran Universitas Gadjah Mada.Yogyakarta.
Notoatmodjo, S. 2012. Promosi Kesehatan dan Ilmu Perilaku. Rineka Cipta. Jakarta.

Notoatmodjo, Soekidjo. 2012. Pendidikan dan Perilaku Kesehatan. Notoatmodjo Jakarta:Rineka Cipta

Notoatmodjo,2014.Ilmu Perilaku Kesehatan. Jakarta:Rineka Cipta.

Notoatmodjo,S. 2012. Metodologi Penelitian Kesehatan. Jakarta: Rineka Cipta.. 2004. Metodologi Penelitian Kesehatan. Jakarta: Rineka Cipta

Nursalam,2014,Konsep dan Penerapan Metodologi Penelitian Ilmu Keperawatan, Jakarta,Salemba Medika;100.

Pusat Data Kementerian Kesehatan (2017) Info datin Situasi dan Analisis Hepatitis. Jakarta: Kementerian Kesehatan RI.

Radji Maksum dalam Hernando dkk, 2018,Jurnal Riset Kesehatan Pemeriksaan Hepatitis B surface Antigen (HbsAg) dan Anti Hbs Pada Ibu Hamil,80-84 (februari)1.

Rara Ayu Sekar dkk,2016,Sayoga dalam Jurnal Penyuluhan Sebagai Komunikator Keluarga Berencana, Vol.2, No.4.

Sanityoso A, Christine G. 2014. Ilmu Penyakit Dalam (Hepatitis Viral Akut) Jilid II Edisi VI. Interna Publishing: Jakarta

Shao, dkk.et al. Maternal Hepatitis B Virus Carier Status and Pregnancy Outcomes; A Propective Cohort Study. BMC Pregnancy and Childbirth,2016;16 (87):1-8

Sitiatava Rizema Putra,2012,Panduan Riset Keperawatan dan Penulisan Ilmiah, Jogjakarta,D-Medika;155.

Sofie, N., Wilopo, S.A.. \& Ismail. D., 2004. Hubungan Perilaku ibu dalam Memanfaatkan Pelayanan Kesehatan Selama Kehamilan dengan Kepatuhan Ibu hamil dalam pemeriksaan BHsAg. Berita Kedokteran Masyarakat, XX. 97-103.

http://jurnalilmiah.stikescitradelima.ac.id/index.php/JI Vol.3,No.2, Januari 2020 
Sugiyono, 2011, Metode Penelitian Kuantitatif, Kualitatif dan R\&D, Bandung : Alfabeta.

Suhartono, 2012.Fisafasat Ilmu Pengetahuan, Jogjakarta:AR-RUZZ

Sumardjo, 2011, Bahan Kuliah Metode Penyuluhan. Jurusan Sosial Ekonomi Pertanian. Institute Pertanian Bogor.

Syafrudin dan Fratidhina, 2009,Promosi Kesehatan Untuk Mahasiswa Kebidanan,Jakarta;TIM.

WHO (2018) Penerapan Kewaspadaan Standar di Pelayanan Kesehatan.

WHO, Behavioral Factors in Immunization for Pregnancy, Geneva, 2010

Wiratmadja. 2011."Pokok-Pokok Penyuluhan Pertanian”.C.V.Yasaguna: Jakarta.

World Health Organization.Haemoglobin Concentrations for The Diagnosis of Anaemia and Assessment of Severity. Vitamin and mineral Nutrition Informatio System. Geneva: WHO 2011. [Online] [Akses 26 Februari 2019.] 